\title{
Assessment of Climate Driven Changes in Flow Series of Alpine Basin: A Case Study of Danube River Basin
}

\author{
Abdul Nasir Laghari \\ Department of Energy and Environment, \\ Quaid-e-Awam University of \\ Engineering, Science and Technology, \\ Nawabshah, Pakistan \\ a.n.laghari@quest.edu.pk
}

\author{
Abdul Rehman Jatoi \\ Department of Energy and Environment, \\ Quaid-e-Awam University of \\ Engineering, Science and Technology, \\ Nawabshah, Pakistan \\ arjatoi@quest.edu.pk
}

\author{
A. Rajper \\ Department of Mechanical Engineering, \\ Quaid -e- Awam University of \\ Engineering, Science and Technology, \\ Nawabshah, Pakistan \\ altafrajpar@yahoo.com \\ Nabi Bux Jalbani \\ Department of Chemical Engineering, \\ Quaid-e-Awam University of \\ Engineering, Science and Technology, \\ Nawabshah, Pakistan \\ n.bux@quest.edu.pk
}

\author{
Gordhan Das Walasai \\ Department of Mechanical Engineering, \\ Quaid-e-Awam University of \\ Engineering, Science and Technology, \\ Nawabshah, Pakistan \\ valasai@quest.edu.pk

\section{Hira Soomro} \\ Department of Basic Sciences and \\ Related Studies, Mehran University of \\ Engineering and Technology, \\ Jamshoro, Pakistan \\ hirasoomro47@gmail.com
}

\begin{abstract}
This study was carried out in order to analyze the climate change driven influence on mean monthly flow series of Danube River and its tributaries during the last century. The study confirms some signs of climate driven alterations in monthly river flow series along with change in flow seasonality during the last century. In spite of this, man-made interference in the basin like i.e. groundwater extraction, irrigation, river regulation, land use alteration and urbanization, has significantly changed Danube flow regime in most areas of the catchment. The analysis of Achleiten station demonstrates that average annual flow regime is a little bit increased. Major increase is observed in winter and autumn months and decrease in summer months. These seasonal alterations clearly signal a future glimpse of reduced water availability in alpine basins. This will mainly occur due to the change in the form of precipitation in winter, from snow to rain and the consequent less snow accumulation, and the early melt of snow storage, less precipitation and high evaporation rate in summer.
\end{abstract}

Keywords-climate change; man-made abstraction; seasonal flow regime; Alpine river

\section{INTRODUCTION}

Earth's atmosphere has experienced an extraordinary warming over the 20th century. The average atmospheric temperature has risen by approximately $0.8^{\circ} \mathrm{C}$ during the last 200 years, and since the ' $80 \mathrm{~s}$, earth has witnessed the warmest years over the last 1400 years. The rise in average global temperature has caused a major change in weather patterns and properties of earth's atmosphere [1]. The temperature increase over the last century emerged in two phases, during 1910-1940 and at higher rate since 1980 . The increase in the average surface temperature has been caused by perturbations in the radiation system of earth's atmosphere. Perturbations might happen due to volcanic eruptions resulting in release of gases, changes in solar irradiation or greenhouse gas emissions. IPCC relates the increase in the average earth surface temperature to human activities [2]. IPCC reported that many river basins in mountain regions would suffer a massive decrease in water resources due to climate change. Due to increased precipitation and decreased evapotranspiration with altitude, mountain regions are characterized by high discharge values [3]. Their contribution in total water supply to global population is far greater than their areas [4]. Their future global water resource role would likely be altered from the anticipated climate change. Therefore, climate change impacts on the hydrological cycle of mountain watersheds and subsequent water availability which is critical for sustainable future water resource planning and management. IPCC reported that the change level is higher in mountain regions-approximately $300 \%$ more than the average global temperature [5-7].

The warming rate in the lower-troposphere rises with elevation. This makes mountainous regions very vulnerable [8]. Therefore, any change in climatic parameters, i.e. temperature and precipitation patterns, will change significantly the snow storage and subsequently alter both timing and volume of the discharge regime of mountain rivers [8-18] and accordingly the water availability in downstream regions [19-20]. This may have severe implications on freshwater systems and their management [21]. Under this study, flow series of Danube river major tributaries originated from European Alps have been investigated to check out the climate change driven signs. This would help water resource planning and development 
managers to understand future changes in alpine region.

\section{STUDY AREA DESCRIPTION}

Danube River is the second largest in European region. It originates from Black Forest Mountains of Germany and cascades into Black Sea. It flows through Germany, Austria, Slovak Republic, Hungary and Croatia, passes through Serbia, Romania and Bulgaria, Ukraine and Moldova (Figure 1). Approximately around 81 million people inhabit within its proximity. The basin is approximately $2900 \mathrm{~km}$ long. It possesses drainage area of about $817000 \mathrm{~km}^{2}$. Plain and hilly areas are around the two thirds of the total basin area, while the remaining one third consists of mountains. Its average flow is approximately $6500 \mathrm{~m}^{3} / \mathrm{sec}$. Its elevation ranges from a few hundred meters at lowlands to over $3000 \mathrm{~m}$ a.s.1 with a mean height of about $475 \mathrm{~m}$ a.s.1.

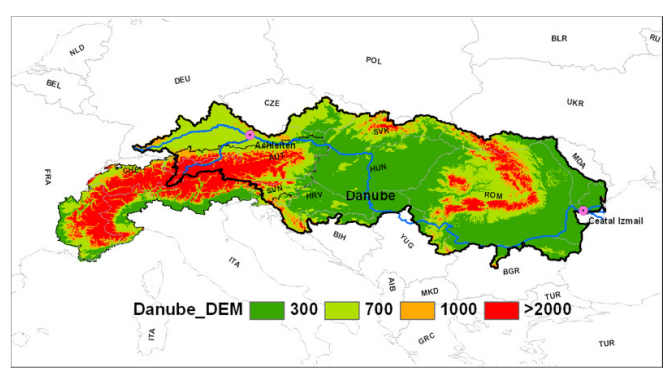

Fig. 1. Geographical map of Danube with both up and downstream gauge stations Achleiten and Ceatal Izmail.

The basin climate varies considerably from mountainous to plain areas due to diverse relief and surface area: Mediterranean climate dominates Sava and Drava catchments, whereas in the western part, high precipitation is the main characteristic of the upper basin due to Atlantic climate while low precipitation and cold winters are the main features of continental climate. The precipitation amount also varies from high altitude to low altitude: the upper part receives around $2000 \mathrm{~mm}$ per year, while the lower basin receives around $500 \mathrm{~mm}$. Similarly, temperature varies from $5-6^{\circ} \mathrm{C}$ at upper Danube to $11-12^{\circ} \mathrm{C}$ at middle to lower part. Snow cover is the dominant feature above $1500 \mathrm{~m}$ a.s.1 from November to March. The seasonal variation rises from western to eastern part [7, $10]$.

\section{RESULTS AND DISCUSSION}

The surface runoff and discharge levels of the main river and its tributaries are highly influenced by seasonal and spatial variations. The tributaries Morava, Tisza, Sava, Drava and Inn are the most vital ones. Overall, Danube River consists of 26 main tributaries. Sava tributary is considered the leading one by average annual discharge volume (approx. $50 \mathrm{~km}^{3}$ ) and the second one by drainage area (approx. $95400 \mathrm{~km}^{2}$ ). Whereas, Inn river is the third main tributary regarding volume with approx. $23 \mathrm{~km}^{3}$ and the seventh by drainage area with $26128 \mathrm{~km}^{2}$. The hydrological characteristics of several Danube tributaries have been analyzed in [22]. Authors in [22] monitored the alpine gauging stations (i.e. Hofkirchen, Passau, Wien), found higher specific discharges compared to low land streams monitored at gauging stations (i.e. Tisza, Silistra, Ceatal Izmail). Alpine tributaries, e.g. Inn, originate at the upper basin and possess high runoff per unit area, whereas lower to middle region of Danube basin produces small values. The mean annual specific value reduces from head waters of Alpine part towards tributaries of the eastern region of Carpathians i.e. 25 to $301 / \mathrm{s} / \mathrm{km}^{2}$ for Alpine headwaters to $14.591 / \mathrm{s} / \mathrm{km}^{2}$ for Drava, towards $6.031 / \mathrm{s} / \mathrm{km}^{2}$ for Tisza. The contribution of Alpine tributaries is more than $25 \%$ of the total mean annual flow and particularly in summer months its average contribution is around $40-45 \%$, and may even reach to $80 \%$ in dry years like in the hot summer of 2003. The Austrian part of Alpine region mostly lies with Danube basin and adds up approximately $20 \%$ of total basin flow volume with mean flow of $1448 \mathrm{~m}^{3} / \mathrm{s}$ [22]. The assessment of monthly flow series of Achleiten station demonstrates that the average annual flow volume is marginally increased [22], however the main effect has been noticed over seasonal flows, i.e. flow volume is increased in winter and autumn and significantly decreased in summer. The increase in volume is most probably due to the increased precipitation rates in winter and recent general temperature increase. Similarly, reduced precipitation rates in summer and early onset of snow melt including high summer evaporation rates are the main cause of reduced summer flows (Figure 2).

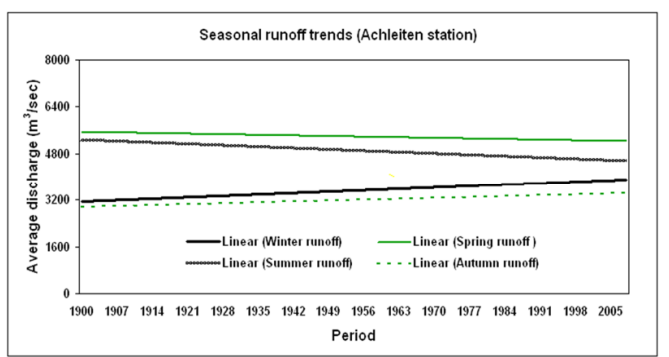

Fig. 2. The linear trends of mean seasonal flow series of Danube at high alpine gauging station Achleiten over 1900-2008. Linear trends indicate a significant shift in seasonality: increase in winter and decrease in summer. Station flow data was provided by GRDC, Germany.

These seasonal tendencies point the future, when the water availability might be affected during summer months like it did in the summer draught of 2003. The situation clearly demonstrates the importance of Alpine contribution. The region fairly offsets the water scarcity through enlarged glacial melt. In a nutshell, there is little indication that climate change has altered seasonal or annual flow volume during the last century. However man-made interferences i.e. groundwater extraction, irrigation demand, urbanizations have remarkably changed river flow regime in most parts of catchment.

\section{CONCLUSION}

This study has been carried out to assess the climate change effect on mean annual and seasonal flow series of Danube River and its tributaries during the 20th century. The study reveals the variations driven by climate change in mean annual and seasonal flow series. The analysis of Achleiten station demonstrates that the average annual flow regime is a little bit increased. Major increase is observed during winter and autumn months and while decrease is observed during summer months. This points out that in future, climate driven changes 
may have a significant effect over snow storage and subsequently alter both timing and volume of the flow regime of mountain rivers and accordingly water availability in downstream regions. Severe implications may emerge on fresh water management and development. However, currently manmade inventions have possibly been the main reason behind Danube flow series alterations.

\section{REFERENCES}

[1] D. L. Hartmann, A. M. K. Tank, M. Rusticucci, L. V. Alexander, S. BrOnnimann, Y. A. R. Charabi, F. J. Dentener, E. J. Dlugokencky, D. R. Easterling, A. Kaplan, "Observations: Atmosphere and Surface", in: Climate Change 2013 the Physical Science Basis: Working Group I Contribution to the Fifth Assessment Report of the Intergovernmental Panel on Climate Change, Cambridge University Press, 2013

[2] IPCC, The Fourth Assessment Report of the Intergovernmental Panel on Climate Change, Geneva, Switzerland, 2007

[3] R. Weingartner, D. Viviroli, B. Schadler, "Water resources in mountain regions: a methodological approach to assess the water balance in a highland-lowland-system", Hydrological Processes, Vol. 21, No. 5, pp. 578-585, 2007

[4] B. Messerli, D. Viviroli, R. Weingartner, "Mountains of the world: vulnerable water towers for the 21 st century", Ambio, Vol. 2004, pp. 2934, 2004

[5] D. Nogues-Bravo, M. B. Araujo, M. Errea, J. Martinez-Rica, "Exposure of global mountain systems to climate warming during the $21 \mathrm{st}$ Century", Global Environmental Change, Vol. 17, No. 3-4, pp. 420-428, 2007

[6] M. Beniston, "Impacts of climatic change on water and associated economic activities in the Swiss Alps", Journal of Hydrology, Vol. 412413, pp. 291-296, 2012

[7] M. Beniston, "Is snow in the Alps receding or disappearing?", WIREs: Climate Change, Vol. 3, No. 4, pp. 349-358, 2012

[8] S. U. Islam, S. J. Dery, "Evaluating uncertainties in modelling the snow hydrology of the Fraser River Basin, British Columbia, Canada", Hydrology and Earth System Sciences, Vol. 21, No. 3, pp. 1827-1847, 2017

[9] B. C. Bates, Z. Kundzewicz, S. Wu, Climate Change and Water, IPCC, Geneva, 2008

[10] D. Vanham, E. Fleischhacker, W. Rauch, "Impact of an extreme dry and hot summer on water supply security in an alpine region", Water Science and Technology, Vol. 59, No. 3, pp. 469-477, 2009

[11] M. M. Elsner, L. Cuo, N. Voisin, J. S. Deems, A. F. Hamlet, J. A. Vano, K. E. Mickelson, S. Y. Lee, D. P. Lettenmaier, "Implications of $21 \mathrm{st}$ century climate change for the hydrology of Washington State", Climatic Change, Vol. 102, No. 1-2, pp. 225-260, 2010

[12] E. Kerkhoven, T. Y. Gan, "Differences and sensitivities in potential hydrologic impact of climate change to regional-scale Athabasca and Fraser River basins of the leeward and windward sides of the Canadian Rocky Mountains respectively", Climatic Change, Vol. 106, No. 4, pp. 583-607, 2011

[13] S. J. Dery, M. A. Hernandez-Henriquez, P. N. Owens, M. W. Parkes, E. L. Petticrew, "A century of hydrological variability and trends in the Fraser River Basin”, Environmental Research Letters, Vol. 7, No. 2, pp. 024019-024028, 2012

[14] F. Strauss, H. Formayer, E. Schmid, "High resolution climate data for Austria in the period 2008-2040 from a statistical climate change model", International Journal of Climatology, Vol. 33, No. 2, pp. 430443,2013

[15] A. Laghari, D. Vanham, W. Rauch, "The Indus basin in the framework of current and future water resources management", Hydrology and Earth System Sciences, Vol. 16, No. 4, pp. 1063-1083, 2012

[16] A. Laghari, D. Vanham, W. Rauch, "To what extent does climate change result in a shift in Alpine hydrology? A case study in the Austrian Alps", Hydrological Sciences Journal, Vol. 57, No. 1, pp. 103-117
[17] T. Kohler, A. Wehrli, M. Jurek, Mountains and Climate Chance: A Global Concern, CDE, SDC and Geographica Bernensia, 2014

[18] D. H. Kang, H. Gao, X. Shi, S. ul Islam, S. J. Dery, "Impacts of a rapidly declining mountain snowpack on streamflow timing in Canada's Fraser River basin", Scientific Reports, Vol. 6, Article Number 19299, 2016

[19] D. Viviroli, D. R. Archer, W. Buytaert, H. J. Fowler, G. Greenwood, A. F. Hamlet, Y. Huang, G. Koboltschnig, I. Litaor, J. I. Lopez-Moreno, "Climate change and mountain water resources: overview and recommendations for research, management and policy", Hydrology and Earth System Sciences, Vol. 15, No. 2, pp. 471-504, 2011

[20] M. Beniston, M. Stoffel, "Assessing the impacts of climatic change on mountain water resources", Science of the Total Environment, Vol. 493, pp. 1129-1137, 2014

[21] Z. Kundzewicz, L. J. Mata, N. W. Arnell, P. Doll, B. Jimenez, K. Miller, T. Oki, Z. Sen, I. Shiklomanov, "The implications of projected climate change for freshwater resources and their management", Hydrological Sciences Journal, Vol. 53, No. 1, pp. 3-10, 2008

[22] K. Tockner, S. E. Bunn, C. Gordon, R. J. Naiman, G. P. Quinn, J. A. Stanford, "4 A Flood plains: critically threatened ecosystems", in: Aquatic Ecosystems: Trends and Global Prospects, pp. 45-61, Cambridge University Press, 2008 